\title{
Cessie als instrument ter afwikkeling van massaschadezaken: in strijd met de openbare orde en goede zeden?
}

\author{
Mr. I. Tillema*
}

\begin{abstract}
1 Inleiding
Privaatrechtelijke handhaving van mededingingsrecht is in zwang, zeker sinds het Hof van Justitie van de Europese Unie in 2000 oordeelde dat eenieder schadevergoeding moet kunnen vorderen bij een mededingingsrechtelijke inbreuk. ${ }^{1}$ Uiteenlopende obstakels lijken echter een daadwerkelijke bescherming van de rechten van benadeelden van dergelijke inbreuken in de weg te staan. Een mogelijk effectief verhaalsmechanisme is de overdracht van een vordering tot schadevergoeding door individuele benadeelden aan een derde, die de vorderingen bundelt en deze vervolgens in eigen naam tracht te innen. ${ }^{2}$ Het is echter de vraag of een derde daartoe mag worden toegelaten, en zo ja, onder welke voorwaarden. Het Landgericht (rechtbank in eerste aanleg) Düsseldorf oordeelde in december 2013 dat de cessies tussen benadeelden van een cementkartel en een commercieel opererende derde in strijd waren met de goede zeden. ${ }^{3}$ De rechter oordeelde de cessies nietig, omdat het proceskostenrisico hierdoor op een ongerechtvaardigde wijze werd verschoven van de individuele benadeelden naar een derde die dit risico niet of onvoldoende kon dragen. In Nederland lopen enkele kartelschadeprocedures waarin derden op vergelijkbare wijze in eigen naam schadevergoeding vorderen, onder meer de partij die in Duitsland
\end{abstract}

Mr. I. Tillema is promovenda aan de Erasmus School of Law van de Erasmus Universiteit Rotterdam.

1. HvJ EG 20 september 2000, C-453/99 (Courage/Crehan). Ook vóór die tijd bestond reeds een levendige praktijk in dit rechtsgebied, zie P. Glazener, Private handhaving, M\&M 2013, afl. 4, p. 117. Glerum-van Aalst en Brand spraken onlangs van een 'gestage opmars van kartelschadevorderingen van gelaedeerden', E.D. Glerum-van Aalst \& S.R. Brand, Privaatrechtelijke handhaving van het mededingingsrecht: recente ontwikkelingen, MvV 2014, afl. 9, p. 227-239.

2. Zie over de effectiviteit of wenselijkheid hiervan bijv. A. Pinna, Financing Civil Litigation: The Case for the Assignment and Securitization of Liability Claims, in: M.L. Tuil \& L. Visscher (red.), New Trends in Financing Civil Litigation in Europe. A Legal, Empirical, and Economic Analysis, Cheltenham: Edward Elgar 2010, p. 109-130 en A.J. Sebok, The Inauthentic Claim, Vanderbilt Law Review 2011, afl. 1, p. 61-139.

3. LG Düsseldorf 17 december 2013, 37 O 200/09 (Kart) U. Daaraan gingen vooraf: LG Düsseldorf 21 februari 2007, 34 O (Kart) 147/05, OLG Düsseldorf 14 mei 2008, VI-U (Kart) 14/07 en BGH 7 april 2009, KZR 42/08. Zie ook A. Stadler, Die Bündelung von gleichgerichteten Ansprüchen durch Inkassozession - Geschäftsmodelle zur Prozessfinanzierung auf dem Prüfstand, Juristenzeitung 2014, afl. 12, p. 613-622.
- vooralsnog - het onderspit moest delven. ${ }^{4}$ Ook in Nederland zal mogelijk de geldigheid van de cessies tussen individuele benadeelden en dergelijke derden aan de kaak worden gesteld. ${ }^{5}$

In deze bijdrage ga ik in op de vraag in hoeverre cessie als instrument ter afwikkeling van massaschade naar Nederlands recht in strijd kan worden geacht met de goede zeden of openbare orde. Daarbij ga ik uit van de feiten waarop de Duitse uitspraak berust, waarvan ik in paragraaf 2 een beknopte beschrijving geef. ${ }^{6}$ In paragraaf 3 bespreek ik bovenstaande vraag. De Europese aanbeveling voor collectief verhaal, voor zover deze is gericht op de financiële middelen van een derde, komt daarbij zijdelings aan de orde. Paragraaf 4 sluit de bijdrage af.

2 De feiten en de beslissing in de Duitse procedure In 2003 heeft de Duitse mededingingsautoriteit een boete opgelegd aan twaalf Duitse cementproducenten wegens kartelvorming in de cementmarkt. ${ }^{7}$ Duitse cementkopers, voornamelijk midden- en kleinbedrijven, stellen dat zij hierdoor aanzienlijke schade hebben geleden. Tussen 2002 en 2009 hebben 36 van deze benadeelden hun vordering op de karteldeelnemers verkocht aan Cartel Damages Claims (hierna: CDC). CDC is een in 2002 opgerichte Belgische onderneming en legt zich toe op het geldend maken van schadevergoedingsvorderingen die zijn ontstaan door mededingingsrechtelijke inbreuken. CDC doet dit onder andere door de vorderingen van benadeelden te kopen, te bundelen en deze vervolgens in eigen naam te innen. Zo ook in de onderhavige procedure, waarmee zij in 2005 tegen zes karteldeelnemers een

4. Hoger beroep is ingesteld, zie < carteldamageclaimscom/portfolios/cdegerman-cement-cartel/> (onder 'Civil proceedings'). Zie ook T. Schreiber, Private Antitrust Litigation in the European Union, The International Lawyer 2010, p. 1157-1172.

5. Zie par. 3.1.

6. Ik bespreek uitsluitend de hier relevante feiten. Zie met name LG Düsseldorf 21 februari 2007, onder 'Tatbestand', OLG Düsseldorf, onder 'Gründe' (6-16) en LG Düsseldorf 17 december 2013, onder 'Tatbestand' (C) en 'Entscheidungsgründe' (96-127).

7. In 2009 en 2013 is deze uitspraak bevestigd, zie OLG Düsseldorf, 26 juni 2009, VI-2a (Kart) 2-6/08, respectievelijk BGH 20 februari 2013, KRB $20 / 12$. 
vordering heeft ingesteld ten bedrage van ongeveer $€ 140$ miljoen.

In grote lijnen bevatten de overeenkomsten tussen CDC en de individuele cementkopers de volgende elementen. De benadeelde verkoopt en draagt over aan CDC de aanspraak op schadevergoeding als beschreven in de overeenkomst. Op grond van de overeenkomst zal CDC de vordering, indien zij deze voldoende succesvol acht, in rechte voor eigen rekening en risico te gelde maken. De overeenkomst verplicht CDC eveneens tot betaling van een koopprijs aan de benadeelde. Deze koopprijs bestaat uit een vaste component ( $€ 100)$ en een variabel deel: een percentage van de uiteindelijke opbrengst die wordt verkregen door een schikking of rechterlijk vonnis. Het individueel overeengekomen percentage varieert tussen $65 \%$ en $85 \%$, afhankelijk van de vraag of, en zo ja, hoeveel de benadeelde bijdraagt aan de proceskosten.

Het Landgericht Düsseldorf heeft deze overeenkomsten gekwalificeerd als cessie (Abtretung) conform $₫ 398$ Bürgerliches Gesetzbuch (BGB). ${ }^{8}$ Hierdoor is CDC rechthebbende van de vorderingen geworden en kan zij deze innen in eigen naam. Het Landgericht heeft voorts geoordeeld dat deze overeenkomsten nietig zijn. De overeenkomsten die zijn gesloten vóór 2008 zijn nietig wegens strijd met (oude) regelgeving over juridische dienstverlening en daarmee wegens strijd met de wet ( $\$ 134$ BGB). Voor de overeenkomsten die zijn gesloten ná 2008 geldt dat deze in strijd zijn met de goede zeden (sittenwidrig, $\$ 138(1) \mathrm{BGB}) .{ }^{9}$ Volgens het Landgericht hebben CDC en de benadeelden zonder gerechtvaardigd belang het proceskostenrisico - met name een eventuele proceskostenveroordeling jegens gedaagden - verschoven naar CDC, die dit risico niet of onvoldoende kan dragen omdat zij ten tijde van de overdracht over onvoldoende financiële middelen beschikte. Ter onderbouwing van dit oordeel stelt het Landgericht voorop dat cessie niet mag worden misbruikt, in die zin dat een minder solvente partij als procespartij naar voren wordt geschoven en de wederpartij daadwerkelijk verhaal van een eventuele proceskostenveroordeling wordt ontnomen. In de onderhavige zaak wordt daarbij het - uit de grondwet afgeleide - beginsel van een evenredige distributie van het proceskostenrisico als uitgangspunt genomen. ${ }^{10}$ Dit principe ligt bijvoorbeeld ten grondslag aan de procesbevoegdheid van een belangenbehartiger die namens benadeelden een representatieve vordering (Verbandsklage) instelt: deze moet over voldoende financiële middelen beschikken om zowel de eigen proces-

8. Naar Duits recht wordt een vordering overgedragen door middel van een overeenkomst tussen cedent en cessionaris.

9. Strijd met de öffentliche Ordnung zal meestal ook strijd opleveren met de gute Sitten, en is daarom niet opgenomen in de uiteindelijke regeling van $\$ 138$ BGB; zie V. van den Brink, De rechtshandeling in strijd met de goede zeden, Den Haag: Boom Juridische uitgevers 2002, p. 144-145 en H.J. van Kooten, Restitutierechtelijke gevolgen van ongeoorloofde overeenkomsten, Deventer: Kluwer 2002, p. 135.

10. Art. 3(1), 20 en 28(1) Grundgesetz; zie hierover A. Bruns, Der Zivilprozess zwischen Rechtsschutzgewährleistung und Effizienz, Zeitschrift für Zivillprozess 2011, afl. 1, p. 37. kosten te kunnen dragen (tot aan de hoogste rechter) als een eventuele proceskostenveroordeling. Een afweging van alle betrokken belangen brengt het Landgericht tot de conclusie dat het bedrijfsmodel van CDC weliswaar aanzienlijk voordeel biedt aan zowel CDC als de benadeelden, maar dat het op een onaanvaardbare, want voor gedaagde nadelige, wijze het principe van een evenredige distributie van het proceskostenrisico negeert. Dat CDC en de benadeelden geen 'bewust verwerpelijke' bedoeling hebben, doet hieraan niet af.

\section{Cessie in strijd met de goede zeden of de openbare orde?}

\subsection{Inleiding}

Terug naar Nederland. De overdracht van (rechts)vorderingen $^{11}$ is een belangrijk instrument ter verkrijging van collectief verhaal. Ondanks het bestaan van de collectieve actie, de Wet collectieve afwikkeling massaschade (WCAM) en andere (buiten)gerechtelijke alternatieven ${ }^{12}$ lijken mededingingsrechtelijke massaschadezaken vooral te worden ingesteld door derden aan wie benadeelden hun vorderingen op de vermeend aansprakelijke partij hebben gecedeerd. ${ }^{13}$ In deze bijdrage ga ik ervan uit dat daarbij sprake is van een 'echte' cessie (art. 3:94 jo. art. 3:84 van het Burgerlijk Wetboek, BW), maar ik merk op dat ook sprake kan zijn van een cessie ter incasso die wordt uitgelegd als lastgeving (art. 7:414 BW), omdat de overeenkomst die daaraan ten grondslag ligt niet de strekking heeft om de vordering in het vermogen van de 'cessionaris ter incasso' te laten vallen. ${ }^{14} \mathrm{Op}$ een verschil tussen cessie en lastgeving kom ik in paragraaf 3.3 nog kort terug.

Als gezegd, tracht de derde, de cessionaris, in eigen naam de gebundelde vorderingen te innen. De financiële drempel - waaronder het proceskostenrisico - die een belangrijk obstakel vormt voor het functioneren van collectief verhaal, ${ }^{15}$

11. Overdracht van een rechtsvordering los van het vorderingsrecht (hier: vordering op naam) is niet mogelijk, art. 3:304 BW.

12. Zie hierover bijv. N. Frenk, Bundeling van vorderingen, $\operatorname{TvPr} 2003$, afl. 4, p. 1418-1423.

13. Rb. Amsterdam 7 maart 2012, ECLI:RBAMS:2012:BV8444, Hof Amsterdam 4 februari 2014, ECLI:NL:GHAMS:2014:244 en Hof Amsterdam 24 september 2013, ECLI:NL:GHAMS:2013:3013 (Equilib/KLM e.a.); Rb. Den Haag 1 mei 2013, ECLI:NL:RBDHA 2013:CA1870 (CDC/Shell); Rb. Rotterdam 17 juli 2013, ECLI:NL:RBROT:2013:5504 (Stichting Elevator Cartel Claim/Kone e.a.); Rb. Amsterdam 4 juni 2014, ECLI:NL:RBAMS:2014:3190 (CDC/Akzo Nobel e.a.); Rb. Midden-Nederland 27 november 2013, ECLI:NL:RBMNE:2013:5978 (East West Debt/UTC e.a.); Hof Amsterdam 7 januari 2014, ECLI:NL:GHAMS:2014:27 (East West Debt/KLM e.a.).

14. Zie hierover Asser/Tjong Tjin Tai 7-IV 2014/280; J.W.A. Biemans, Rechtsgevolgen van stille cessie (Serie Onderneming en Recht, deel 65), Deventer: Kluwer 2011, nr. 33 en 34; HR 21 oktober 1983, NJ 1984/254 (Zomerdijk/Goudsblom) en HR 27 november 2009, ECLI:NL:HR:2009:BH2162(VEB/WOL).

15. Zie bijv. het rapport van Civic Consulting en Oxford Economics uit 2008 (in opdracht van DG SANCO), Evaluation of the Effectiveness and Efficiency of Collective Redress Mechanisms in the European Union, Final Report - Part I: Main Report, beschikbaar op <eceuropaeu/ consumers/redress_cons/finalreportevaluationstudypart 1-final2008-11-26. $\mathrm{pdf}>$. 
wordt hierdoor verplaatst van de individuele benadeelden naar een derde. Kennelijk wegen voor deze derden de voordelen die cessie biedt als instrument voor collectief verhaal (zoals de mogelijkheid tot het vorderen van schadevergoeding en de zekerheid ten opzichte van de benadeelden dat het deel van de opbrengst dat is bestemd voor de derde ook daadwerkelijk wordt ontvangen) op tegen de nadelen (zoals de tijd- en kosteninvestering in het zoeken en benaderen van benadeelden, de complexe administratie en het onderzoek naar en de onderbouwing van individuele rechtsposities). ${ }^{16}$ Dit hangt waarschijnlijk samen met het feit dat mededingingsrechtelijke inbreuken als de onderhavige een relatief beperkt aantal specifieke benadeelden kennen die aanzienlijke schade hebben geleden, en in de collectieve actie - nog - geen schade kan worden gevorderd. ${ }^{17}$

Uit enkele gepubliceerde uitspraken in kartelschadezaken blijkt dat ook in Nederland de geldigheid van dit soort cessies mogelijk aan de orde zal worden gesteld. ${ }^{18}$ In de volgende paragrafen ga ik hierop in binnen het toetsingskader van art. 3:40 BW, op grond waarvan een overeenkomst wegens strijd met de wet, de goede zeden of de openbare orde ongeldig (nietig dan wel vernietigbaar) kan zijn. Ik bespreek allereerst de vraag of het aangaan respectievelijk de inhoud of strekking van de overeenkomst in strijd is met een dwingende wetsbepaling en om die reden (ver)nietig(baar) op grond van art. 3:40 lid 2 en 3 dan wel lid 1 BW (par. 3.2). Vervolgens ga ik na of de inhoud of strekking van de overeenkomst anderszins in strijd is met de goede zeden of de openbare orde, als bedoeld in art. 3:40 lid $1 \mathrm{BW}$ (par. 3.3). Daarbij stel ik voorop dat de wederpartij, de debitor cessus, een beroep kan doen op art. 3:40 BW - een rechter dient een nietigheid mogelijk zelfs ambtshalve vast te stellen ${ }^{19}$ - maar dat een rechter niet snel zal overgaan tot een dergelijke ingrijpende begrenzing van de contractsvrijheid. ${ }^{20}$

\subsection{Overeenkomst in strijd met een dwingende wetsbepaling?}

Over mogelijke strijd met een dwingende wetsbepaling in de onderhavige situatie kan ik kort zijn. Anders dan in Duitsland is in Nederland de juridische dienstverlening niet gereguleerd, afgezien van die door advocaten, notarissen en gerechtsdeur-

16. Zie over de voor- en nadelen bijv. W.M. Schonewille, De financiering van collectieve acties, NJB 2007/2132, I.N. Tzankova \& C.J.M. van Doorn, Effectieve en efficiënte afwikkeling van massaschade: terug naar de kern van het collectieve actierecht, in: F.M.A. 't Hart, Collectieve acties in de financiële sector, Amsterdam: NIBE-SVV 2009, p. 106, J.H. Lemstra, Belangenorganisaties als procespartij, in: F.M.A. 't Hart, Collectieve acties in de financiële sector, Amsterdam: NIBE-SVV 2009, p. 51, W.H. van Boom, Collectieve handhaving van het consumentenrecht, in: M.B.M. Loos \& W.H. van Boom, Handhaving van het consumentenrecht (Preadviezen VBR), Deventer: Kluwer 2010 en Pinna 2010, p. 111.

17. Zie het voorontwerp voor een wetsvoorstel dat strekt tot invoering van een collectieve schadevergoedingsactie, <wwwinternetconsultatienl/ motiedijksma>.

18. Zie de eerste vier uitspraken die zijn opgenomen in noot 13 .

19. Op grond van art. 24 en 25 Rv, zie Van den Brink 2002, p. 35 en Asser/ Hartkamp \& Sieburgh 6-III 2014/312, 330 en 607.

20. Vgl. Asser/Hartkamp \& Sieburgh 6-III 2014/314 en 615. waarders. Het aangaan van een overeenkomst tot cessie tussen CDC en de benadeelden is hier dan ook geen rechtshandeling in strijd met een dwingende wetsbepaling zoals bedoeld in art. 3:40 lid 2 en $3 \mathrm{BW}$. Zo is hier geen sprake van verkrijging van de vordering door een advocaat, zoals bedoeld in art. 3:43 BW. Partijen zoals CDC zijn eveneens vrij om resultaatgerelateerde afspraken te maken. ${ }^{21}$ Verplicht dan vervolgens de inhoud van de overeenkomst tot een dwingende wettelijk verboden prestatie dan wel leidt de strekking ervan tot een wetsovertreding, zodat deze in strijd is met de goede zeden of openbare orde zoals bedoeld in art. 3:40 lid $1 \mathrm{BW}$ ? Ik meen van niet. Het bezwaar van de gedaagden in de Duitse procedure was dat zij door de overeenkomsten tussen CDC en de benadeelden werden geconfronteerd met een ander dan de oorspronkelijke crediteur(en), en dat een eventuele proceskostenveroordeling moest worden verhaald op deze - ten tijde van de overdrachten kennelijk onvoldoende solvente - derde. Nederland kent echter geen dwingendrechtelijke regeling die bepaalt dat een derde zoals CDC in geval van overdracht moet beschikken over voldoende financiële middelen, of een anderszins toepasselijke dwingende wetsbepaling.

\subsection{Overeenkomst in strijd met de goede zeden of de openbare orde?}

De open normen 'goede zeden' en 'openbare orde' van art. 3:40 lid $1 \mathrm{BW}$ kunnen de rechter aanleiding geven om een rechtshandeling wegens haar inhoud of strekking nietig te achten omdat deze ongeschreven 'fundamentele beginselen van de rechtsorde of van maatschappelijk behoren' schendt. ${ }^{22}$ Van den Brink geeft aan dat de inhoud (van de goede zeden) moet worden gevonden in een 'minimale in de maatschappij levende overeenstemming omtrent de inhoud van de voorschriften van de moraal'. ${ }^{23}$ Deze overeenstemming kan met name uit wetgeving en rechtspraak worden afgeleid (en, zoals Zwalve aanvult, uit empirisch onderzoek ${ }^{24}$ ).

Wat betekent dit voor de onderhavige casus? De waarden of belangen die hier mogelijk zijn geschonden, kunnen worden geplaatst in de categorie 'grove veronachtzaming van de rechtmatige belangen van derden'. ${ }^{25}$ CDC en de benadeelden hebben immers het proceskostenrisico verschoven naar een partij die dit niet of onvoldoende kan dragen, waardoor de wederpartij op ongerechtvaardigde wijze wordt geconfronteerd met een mogelijk gebrek aan verhaal van haar proceskostenveroordeling. Althans, zo oordeelde de Duitse rechter. Deze redenering valt uiteen in twee onderdelen, die ik voor Nederland hierna afzonderlijk zal bespreken: (a) misbruik van cessie door

21. Vgl. Hof Amsterdam 13 december 2011, ECLI:NL:GHAMS: 2011:BU8763.

22. Parl. Gesch. Inv. Boeken 3, 5 en 6, p. 1141 (L.v.Antw. II Inv.). Aangezien het onderscheid tussen goede zeden en openbare orde wat gevolg betreft niet relevant is, laat ik dat hier terzijde.

23. Van den Brink 2002, p. 233-234.

24. W.J. Zwalve, Redelijkheid en billijkheid, goede zeden en restitutie (Boekbespreking), WPNR (2002) 6501, p. 608, met verwijzing naar Van den Brink 2002, p. 163.

25. Zie over deze categorie Van den Brink 2002, p. 216-219. 
het naar voren schuiven van een onvoldoende solvente partij en (b) de daardoor ongerechtvaardigde benadeling van de aangesproken partij.

\section{Ad a. Misbruik van cessie en de toets van de financiële middelen van de cessionaris}

Bij de toets of sprake is van misbruik van cessie door het naar voren schuiven van een partij die het proceskostenrisico niet of onvoldoende kan dragen, stuit ik allereerst op een feitelijk obstakel. Voor de bepaling daarvan is immers inzage nodig in de financiële toestand van de cessionaris. Die inzage werd in de Duitse zaak - toevalligerwijs - verkregen omdat CDC bij aanvang van de procedure een verzoek had ingediend tot verlaging van het geldelijk belang (en de daaraan verbonden hoogte van de proceskosten) vanwege haar financiële situatie. ${ }^{26}$ Nederland kent geen regeling die een dergelijk verzoek mogelijk maakt, noch, als gezegd, een regeling die bepaalt dat een derde zoals CDC moet beschikken over voldoende financiële middelen, dan wel daarin inzage zou moeten geven. Uit rechtspraak blijkt evenmin dat dergelijke vereisten worden gesteld. In een van de hiervoor aangehaalde kartelschadezaken oordeelde Hof Amsterdam onlangs dat het op commerciële basis proberen te verzilveren van de aanspraken op schadevergoeding van diverse benadeelden vooralsnog niet de conclusie rechtvaardigde dat sprake was van misbruik van (proces)recht door deze eisende partij, noch van anderszins ontoelaatbare gedragingen in het kader van het verkrijgen van schadevergoeding. $^{27}$

Uit het gebrek aan zo'n regeling of rechtspraak op dit punt zou kunnen worden afgeleid dat inzage in de financiële middelen van de eisende partij niet nodig of wenselijk wordt geacht. Een aanknopingspunt voor een andersluidend standpunt kan worden gevonden in de Europese aanbeveling voor collectief verhaal. ${ }^{28}$ Daarbij merk ik allereerst op dat deze niet-bindende aanbeveling en bijbehorende mededeling van de Europese Commissie van juni 2013 niet van toepassing zijn op zaken als de onderhavige. ${ }^{29}$ Het oordeel van de Duitse rechter is echter in lijn met aanbeveling 4 onder c, 14 en 15 onder c. Uit deze beginselen volgt dat een vertegenwoordigende organisatie onder meer dient te beschikken over voldoende financiële middelen, dat een eisende partij moet worden verplicht bij de aanvang van de procedure de oorsprong aan te geven van de middelen die zij zal gebruiken ter ondersteuning van de rechtsvordering, en dat, als financiële middelen van een derde partij worden gebruikt, de eisende partij in staat moet zijn om een

26. Zie $₫ 89$ a Gesetz gegen Wettbewerbsbeschränkungen en $₫ 12$ Gesetz gegen den unlauteren Wettbewerb.

27. Zie Hof Amsterdam 7 januari 2014, ECLI:NL:GHAMS:2014:27, r.o. 2.10. Vgl. ook Hof Den Haag 28 mei 2013, ECLI:NL:GHDHA: 2013:CA0587, r.o. 2.4 .

28. Recommendation 2013/396/EU en Communication COM(2013)401 final. Zie hierover bijv. L.E.J. Korsten \& W.J.L. de Clerck, Aanbeveling Europese Commissie: gemeenschappelijke beginselen voor collectief verhaal bij schending van Unierechten (III), Bb 2013/67, p. 1-6 en I. Tillema, De representatieve vordering: dekt de Europese vlag de Nederlandse lading?, NTBR 2014, afl. 5, p. 194-202.

29. Zie de definities in Aanbeveling 3 onder a en $d$. proceskostenveroordeling te dragen in geval van verlies van de procedure. De 'sanctie' die de aanbeveling op niet-naleving van de bepalingen stelt, is 'verlies van haar status' (als 'aangewezen instantie', zie aanbeveling 5) of schorsing van de procedure (aanbeveling 15).

Voor het standpunt dat een eisende partij in een massaschadezaak over voldoende financiële middelen dient te beschikken ter voorkoming van misbruik, kan ook aansluiting worden gezocht bij art. 1006 van het Wetboek van Burgerlijke Rechtsvordering $(\mathrm{Rv})$. Deze bepaling is uitsluitend van toepassing op de procedure waarbij bepaalde belangenbehartigers bedingen in algemene voorwaarden onredelijk bezwarend kunnen laten verklaren door het Hof Den Haag (zie art. 6:240-242 BW). Op grond van art. $1006 \mathrm{Rv}$ kan de rechter op verzoek van partijen bevelen dat een proceskostenzekerheid wordt gesteld indien gerede twijfel bestaat of de wederpartij daarvoor voldoende verhaal zal bieden (vergelijkbaar met art. $224 \mathrm{Rv}$ ). Deze voorziening is blijkens de parlementaire geschiedenis opgenomen omdat:

'(...) het verhaal van een proceskostenveroordeling problemen kan geven, wanneer de wederpartij slechts bestaat uit niet geïndividualiseerde ondernemers of wanneer niet bij name genoemde leden van een vereniging zich trachten te verschuilen achter een insolvente vereniging. Ook een rechtspersoon die als aanlegger optreedt kan trouwens onvoldoende solvent blijken te zijn voor de onderhavige proceskosten. De rechter zal moeten uitmaken of in een concreet geval van de bedoelde gerede twijfel sprake is. ${ }^{30}$

De bepaling heeft echter een zeer beperkt toepassingsbereik, zowel wettelijk als in de praktijk. ${ }^{31}$ Dat neemt niet weg dat, meer algemeen, in de literatuur af en toe geluiden opgaan om van iedereen die een procedure aanhangig maakt, te verlangen dat hij eerst zekerheid stelt voor de betaling van proceskosten. ${ }^{32}$ Een dergelijke algemene regeling bestaat echter niet, mogelijk vanwege onverenigbaarheid met art. 6 van het Europees Verdrag tot bescherming van de rechten van de mens en de fundamentele vrijheden (EVRM).

Een wetsbepaling die specifiek het oog heeft op bescherming van de wederpartij (schuldenaar) tegen misbruik van cessie, is art. 6:144 BW. Ingevolge dit artikel staat de vorige schuldeiser in voor de nakoming door de nieuwe schuldeiser van de verplichtingen die uit het schuldeiserschap of uit nevenrechten voortvloeien en op de nieuwe schuldeiser zijn overgegaan. Met deze bepaling is beoogd te voorkomen dat een schuldeiser zijn vordering cedeert aan een minder solvente cessionaris en daar-

30. Parl. Gesch. Wijziging Rv e.a.w. (Inv. 3, 5 en 6), p. 366.

31. Vgl. W. Heemskerk, GS Burgerlijke rechtsvordering (losbl.), Deventer: Kluwer, commentaar op art. $1006 \mathrm{Rv}$.

32. Asser/Van Schaick 2011/203; vgl. W. Heemskerk, Zekerheidstelling voor proceskosten, in: M.L. Hendrikse \& A.W. Jongbloed (red.), De toekomst van het Nederlands burgerlijk procesrecht, Deventer: Kluwer 2004, p. 207-208. 
mee de schuldenaar in een slechtere positie brengt. ${ }^{33}$ Meijers noemt in zijn toelichting als voorbeelden de verplichting van de pandhouder als een goed pandhouder voor de zaak zorg te dragen (art. 3:243 BW), de pandgever kennis te geven van de verkoop van het pand (art. 3:252 BW) en het overschot uit te keren aan de pandgever (art. 3:253 BW). Biemans meent dat ook de verplichting tot vergoeding van proceskosten uit hoofde van een proceskostenveroordeling kan worden gezien als een verplichting die voortvloeit uit het schuldeiserschap. ${ }^{34} \mathrm{Hij}$ stelt daarbij dat wanneer de cessionaris deze verplichting niet nakomt, een schadevergoedingsverplichting kan ontstaan voor de oude schuldeiser jegens de schuldenaar. Toegepast op de onderhavige casus zou dat betekenen dat de aangesproken partij de proceskostenveroordeling niet alleen op CDC kan verhalen, maar ook op de individuele benadeelden.

In het licht van bescherming van de schuldenaar is dit standpunt verdedigbaar, ook wanneer de vergelijking wordt getrokken met art. 6:155 BW, waaruit volgt dat voor schuldoverneming de toestemming van de schuldeiser is vereist. De schuldenaar, de aangesproken partij, is immers de (eventuele) schuldeiser ten aanzien van een proceskostenveroordeling. Ik betwijfel echter of een verplichting tot het vergoeden van proceskosten zodanig voortvloeit uit het schuldeiserschap dat deze met de overdracht is overgegaan op een nieuwe schuldeiser. Het lijkt mij dat deze (eventuele) verplichting niet eerder ontstaat dan wanneer een vordering is ingesteld. Een eventuele proceskostenveroordeling komt dan ten laste van de materiële procespartij; ${ }^{35}$ bij cessie is dat de cessionaris. De cedent, de oude schuldeiser, is geen partij bij de procedure en de proceskostenveroordeling heeft op hem ook geen betrekking. Dat hij hiervoor desondanks instaat omdat hij 'ooit' schuldeiser was, gaat mij wat ver, nog afgezien van de consequentie van deze uitleg van art. 6:144 BW voor de praktijk (het is de vraag of een benadeelde zijn vordering nog zal overdragen wanneer hij daarbij via een omweg nog steeds het proceskostenrisico draagt). Wellicht gaat de redenering van Biemans dan ook eerst op wanneer de (mogelijke) verplichting tot betaling van de proceskostenveroordeling daadwerkelijk bestaat ten tijde van de overdracht, oftewel wanneer de procedure al is ingesteld. Meer in het algemeen zou ook kunnen worden betwist dat, gelet op de afwijzing van de vordering, sprake is van 'schuldeiserschap', laat staan van een daaruit voortvloeiende verplichting.

Tot slot merk ik in dit verband terzijde op dat het verhaal van de proceskostenveroordeling op de individuele benadeelden wél zou kunnen plaatsvinden wanneer niet sprake is van cessie, maar van lastgeving ter incasso. In dat geval zijn de benadeel-

33. C.J. van Zeben, Parlementaire Geschiedenis van het Nieuwe Burgerlijk Wetboek. Boek 6. Algemeen gedeelte van het verbintenissenrecht, Deventer: Kluwer 1981, p. 535 (TM).

34. J.W.A. Biemans, GS Verbintenissenrecht (losbl.), Deventer: Kluwer, commentaar op art. 6:144 BW, aant. 2.1; Biemans 2011, nr. 369 en 640-645.

35. Zie bijv. E.J. Numann, GS Burgerlijke rechtsvordering (losbl.), Deventer: Kluwer, commentaar op art. 237 Rv, aant. 14. den (lastgevers) de materiële procespartijen, met als gevolg dat de wederpartij de proceskostenveroordeling op hen kan verhalen.

Kan nu uit de hiervoor beschreven regelgeving en rechtspraak een 'minimale in de maatschappij levende overeenstemming omtrent de inhoud van de voorschriften van de moraal' worden afgeleid wat betreft het belang van de wederpartij bij een voldoende solvente eisende partij, zodanig dat bij schending van dat belang de overeenkomst tot cessie nietig moet worden geacht? Tenzij sprake is van een overduidelijk opzettelijke vervanging van de oorspronkelijke schuldeisers door een onvoldoende solvente derde, uitsluitend om de wederpartij verhaal van een proceskostenveroordeling te ontnemen, lijkt mij dat niet. Ik onderbouw dat, tot slot, mede aan de hand van het volgende.

\section{Ad b. De belangenafweging}

Het Landgericht oordeelde dat de wederpartij op ongerechtvaardigde wijze is geconfronteerd met een mogelijk gebrek aan verhaal van haar proceskostenveroordeling. Daarbij werd het belang van CDC/benadeelden bij de cessie afgewogen tegen dat van gedaagden bij een evenredige distributie van het proceskostenrisico, een beginsel dat, als gezegd, uit de Duitse grondwet kan worden afgeleid. Zou deze belangenafweging in Nederland tot dezelfde conclusie leiden? Ik meen van niet, omdat er een wezenlijk verschil bestaat tussen beide proceskostensystemen. Ik werk dit uit.

In Nederland geldt hetzelfde uitgangspunt voor de proceskostenregeling als in Duitsland: in beginsel betaalt de verliezende partij de proceskosten van de wederpartij. ${ }^{36}$ Ook de gedachte die daaraan ten grondslag ligt, is vergelijkbaar - al is die in Nederland niet grondwettelijk gewaarborgd. Hier vorderen de billijkheid en rechtvaardigheid dat de verliezende partij de proceskosten van de winnende partij betaalt. ${ }^{37}$ In de uitwerking van de regeling eindigt echter de gelijkenis. In tegenstelling tot in Nederland, geldt in Duitsland namelijk een volledig indemnisatiebeginsel. Dat betekent dat de volledige proceskosten worden vergoed, dus ook de - strak gereguleerde en voorafgaand aan de procedure vastgestelde - advocaatkosten. In Nederland stelt het compensatiestelsel (partijen dragen hun eigen kosten) het indemnisatiestelsel deels terzijde, omdat een groot gedeelte van de advocaatkosten van de winnende partij voor eigen rekening blijft. Dit komt door de vaststelling van

36. Zie art. 237 Rv en $\$ 91$ ZPO. Zie voor een beschrijving van het Duitse proceskostensysteem bijv. B. Hess \& R. Hübner, General Overview and Trends in the German Civil Litigation Cost System, in: C. Hodges, S. Vogenauer \& M. Tulibacka (red.), The Costs and Funding of Civil Litigation. A Comparative Perspective, Oxford/Portland: Hart Publishing 2010, p. 349-371.

37. Voor een - kritische - beschrijving van de geschiedenis van de grondslag van de proceskostenveroordeling, zie W.L. Haardt, De veroordeeling in de kosten van het burgerlijk geding, Den Haag: Martinus Nijhoff 1945 , p. 11-19. Zie ook Parl. Gesch. Wijziging Rv e.a.w. (Inv. 3, 5 en 6), p. 36 en Asser/Van Schaick 2011/128, met verdere literatuurverwijzingen. 
dit deel van de proceskostenvergoeding aan de hand van het Liquidatietarief. ${ }^{38}$

Het belang van cessie als instrument ter collectief verhaal voor benadeelden en derde beschreef ik in paragraaf 3.1. In de bepaling van het belang van gedaagde is het relevant om te bezien waartoe het verschil tussen het Nederlandse en Duitse proceskostensysteem leidt wat betreft het proceskostenrisico. Ik illustreer dit met een voorbeeld, ietwat geabstraheerd van de Duitse feiten. ${ }^{39}$

Stel dat ieder van dertig benadeelden meent schade te hebben geleden van ongeveer $€ 5$ miljoen. $\mathrm{Zij}$ dragen hun vorderingen over aan een derde, die vervolgens de gebundelde vorderingen ad $€ 150$ miljoen in rechte instelt. Een mogelijke proceskostenveroordeling in Nederland zou dan ongeveer $€ 20.000$ kunnen bedragen. ${ }^{40}$ Dit proceskostenrisico is exact hetzelfde wanneer een individuele benadeelde een vordering van $€ 5$ miljoen zou indienen. Wanneer alle dertig partijen een individuele procedure instellen, is het totale proceskostenrisico voor gedaagde $€ 600.000$. Voor gedaagde is het dus, wat betreft het proceskostenrisico, irrelevant of er één individuele procedure of een gebundelde procedure wordt ingesteld; het proceskostenrisico (de hoogte van een eventuele proceskostenvergoeding) blijft hetzelfde. Daarnaast is gedaagde gebaat bij bundeling zodra er meer dan één individuele vordering tegen hem wordt ingesteld; al vanaf dat moment loopt hij een hoger proceskostenrisico. Voor Duitse partijen ligt dit anders. Daar zou een eventuele proceskostenveroordeling in een individuele zaak ongeveer $€ 159.000$ kunnen bedragen, en in de gebundelde zaak ongeveer $€ 875.000 .{ }^{41}$ Wanneer alle dertig partijen een individuele procedure instellen, is het totale proceskostenrisico voor gedaagde $€ 4$.770.000. Ook hier is gedaagde dus gebaat bij bundeling, maar niet eerder dan wanneer zes of meer individuele partijen een vordering instellen; vanaf dat moment loopt hij een hoger proceskostenrisico. Bij de vergelijking tussen één individuele vordering ten opzichte van de gebundelde vordering is de financiële status van de cessionaris voor een Duitse gedaagde echter belangrijker dan in Nederland, omdat door de bundeling het proceskostenrisico hoger is dan bij één individuele vordering.

Bij dit voorbeeld moet de kanttekening worden geplaatst dat het geen eerlijke vergelijking is wat betreft de daadwerkelijke proceskosten, omdat in de Nederlandse proceskostenveroordeling niet de daadwerkelijke kosten van de advocaat zijn opgenomen. Het gaat mij hier uitsluitend om een illustratie van het proceskostenrisico, zoals dat tot uitdrukking wordt

38. Zie <rechtspraaknl/Procedures/Landelijkeregelingen/Sector-civielrecht/ Pages/Liquidatietariefrechtbanken-en-gerechtshovenaspx $>$.

39. Het voorbeeld is een vereenvoudiging van een eventuele werkelijkheid; zo is geen rekening gehouden met eventuele deskundigenrapportage(s) en de kosten van het voeren van individuele verweren.

40. Het griffierecht in deze zaak bedraagt $€ 3829$. Stel dat er vijf proceshandelingen plaatsvinden, dan bedraagt een eventuele vergoeding van de advocaatkosten van de wederpartij $(5 \times € 3211=) € 16.055$.

41. Zie <wwwprozesskostenrechnerde $>$. gebracht in de proceskostenveroordeling in zaken met een hoog geldelijk belang. Wat ook zij van het oordeel van de Duitse rechter, het belang van gedaagde op een solvente wederpartij bij een gebundelde vordering is in Duitsland groter dan in Nederland, waar het bij vorderingen van deze omvang geen verschil makt of deze individueel dan wel gebundeld worden ingesteld, en waar bundeling bovendien al een voordeel oplevert zodra meer dan één individuele vordering wordt ingesteld. Gelet ook op de belangen van vooral de benadeelden bij (het aangaan en) de instandhouding van de overdracht, zou in Nederland de belangenafweging mijns inziens dus anders moeten uitvallen. Dit zou eerst anders zijn indien voor collectief verhaal een aanvullende of volledige proceskostenvergoeding wordt toegekend, zoals sommigen bepleiten. ${ }^{42}$

\section{Conclusie}

Op basis van de hiervoor besproken regelgeving en rechtspraak concludeer ik dat een verstrekkend oordeel zoals dat van de Duitse rechter in Nederland niet direct voor de hand ligt. Zolang het morele toetsingskader niet meer is geobjectiveerd en concreet ingevuld, ${ }^{43}$ lijkt mij dat een vordering tot (kartel)schadevergoeding in beginsel door eenieder zou moeten kunnen worden ingesteld, althans dat een daaraan ten grondslag liggende cessie niet in strijd kan worden geacht met de goede zeden en openbare orde. Het is afwachten of de Nederlandse rechter derden zoals CDC, in de woorden van Haardt, 'met een vriendelijk oog' zal bezien.

Dat neemt niet weg dat, ook in het licht van de Europese aanbeveling, zou kunnen worden nagedacht over de vraag of voor massaschadezaken een regeling voor het stellen van proceskostenzekerheid zou moeten worden vormgegeven, al dan niet aan de hand van een daaraan voorafgaande 'financiële-middelentest'. Daarbij spelen dan vragen een rol zoals aan de hand van welke maatstaven zo'n zekerheid of test moet worden beoordeeld, hoe de belangen worden gewaarborgd van degene die inzage in zijn middelen geeft, de rol van art. 6 EVRM, of de mogelijkheid tot het leggen van conservatoir beslag niet voldoende zekerheid geeft, wat de rechtvaardiging is voor transparantie in uitsluitend dit soort zaken, enzovoort. In het licht van het functioneren van collectief verhaal lijkt mij een dergelijke regeling echter een beter, want minder ingrijpend, middel dan de nietigheid van de cessies.

42. E.-J. Zippro, Privaatrechtelijke handhaving van mededingingsrecht, Deventer: Kluwer 2009, p. 513, met verwijzing naar M.F.J. Haak \& I.W. VerLoren van Themaat, De mogelijkheden voor civielrechtelijke handhaving van de mededingingsregels in Nederland, Amsterdam: Houthoff Buruma 2005, p. 95.

43. Vgl. G.E. van Maanen, Perverse prikkels, NTBR 2009/16. Zie ook Kamerstukken II 2011/12, 33126, 6, p. 6. 